\title{
Review \\ Targeting Systemic Sclerosis from Pathogenic Mechanisms to Clinical Manifestations: Why IL-6?
}

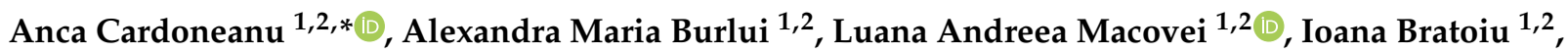 \\ Patricia Richter ${ }^{1,2}$ and Elena Rezus ${ }^{1,2}$ \\ 1 Department of Rheumatology, University of Medicine and Pharmacy "Grigore T Popa", \\ 700115 Iasi, Romania; maria-alexandra.burlui@umfiasi.ro (A.M.B.); luana.macovei@umfiasi.ro (L.A.M.); \\ ioana.bratoiu@umfiasi.ro (I.B.); patricia.richter@umfiasi.ro (P.R.); elena.rezus@umfiasi.ro (E.R.) \\ 2 Rehabilitation Hospital, 700661 Iasi, Romania \\ * Correspondence: anca.cardoneanu@umfiasi.ro
}

check for updates

Citation: Cardoneanu, A.; Burlui,

A.M.; Macovei, L.A.; Bratoiu, I.;

Richter, P.; Rezus, E. Targeting

Systemic Sclerosis from Pathogenic

Mechanisms to Clinical

Manifestations: Why

IL-6? Biomedicines 2022, 10, 318.

https://doi.org/10.3390/

biomedicines 10020318

Academic Editors: Yong-Gil Kim and Michal Tomcik

Received: 29 December 2021

Accepted: 26 January 2022

Published: 29 January 2022

Publisher's Note: MDPI stays neutral with regard to jurisdictional claims in published maps and institutional affiliations.

Copyright: (C) 2022 by the authors. Licensee MDPI, Basel, Switzerland. This article is an open access article distributed under the terms and conditions of the Creative Commons Attribution (CC BY) license (https:// creativecommons.org/licenses/by/ $4.0 /)$.

\begin{abstract}
Systemic sclerosis (SS) is a chronic autoimmune disorder, which has both cutaneous and systemic clinical manifestations. The disease pathogenesis includes a triad of manifestations, such as vasculopathy, autoimmunity, and fibrosis. Interleukin-6 (IL-6) has a special role in SS development, both in vascular damage and in the development of fibrosis. In the early stages, IL-6 participates in vascular endothelial activation and apoptosis, leading to the release of damage-associated molecular patterns (DAMPs), which maintain inflammation and autoimmunity. Moreover, IL-6 plays an important role in the development of fibrotic changes by mediating the transformation of fibroblasts into myofibroblasts. All of these are associated with disabling clinical manifestations, such as skin thickening, pulmonary fibrosis, pulmonary arterial hypertension (PAH), heart failure, and dysphagia. Tocilizumab is a humanized monoclonal antibody that inhibits IL- 6 by binding to the specific receptor, thus preventing its proinflammatory and fibrotic actions. Anti-IL-6 therapy with Tocilizumab is a new hope for SS patients, with data from clinical trials supporting the favorable effect, especially on skin and lung damage.
\end{abstract}

Keywords: systemic sclerosis; interleukin-6; Tocilizumab; pulmonary fibrosis

\section{Introduction}

Systemic sclerosis (SS) is a chronic autoimmune disease that has both cutaneous and systemic clinical manifestations, with the latter being associated with high disease morbidity [1]. The pathogenic mechanisms of this condition are not yet fully understood. However, it is known that the pathogenesis of the disease is composed of a triad: vasculopathy, autoimmunity, and fibrosis [2]. All these mechanisms are interconnected, with each having a particular role in the occurrence of clinical manifestations and disease progression. Immunological mechanisms include both innate and adaptative immunity and involve many cells, such as: B and T lymphocytes, mast cells, macrophages, and dendritic cells [3]. Vasculopathy is characterized by damage and endothelial activation and participates in the initiation and perpetuation of autoimmunity [4]. Activation of fibroblasts and excess deposition of extracellular matrix causes the appearance of fibrosis, which is also related to autoimmunity and vasculopathy [3].

In the early stage of the disease, an inflammatory profile was highlighted, characterized by an increased secretion of proinflammatory cytokines, with the predominant immune response being Th1 and Th17 cells [5]. Moreover, innate immunity, by activating NK/NKTlike cells, plays a decisive role in this initial stage of the disease [6]. The late stage of SS has a predominant Th2-type immune response and is defined by the presence of fibrotic changes [5]. Knowing these important data involved in the pathogenesis of the disease, numerous studies have correlated the clinical manifestations with the excessive secretion 
of some molecules, with the latter being considered potential biomarkers of the disease [7] (Figure 1).

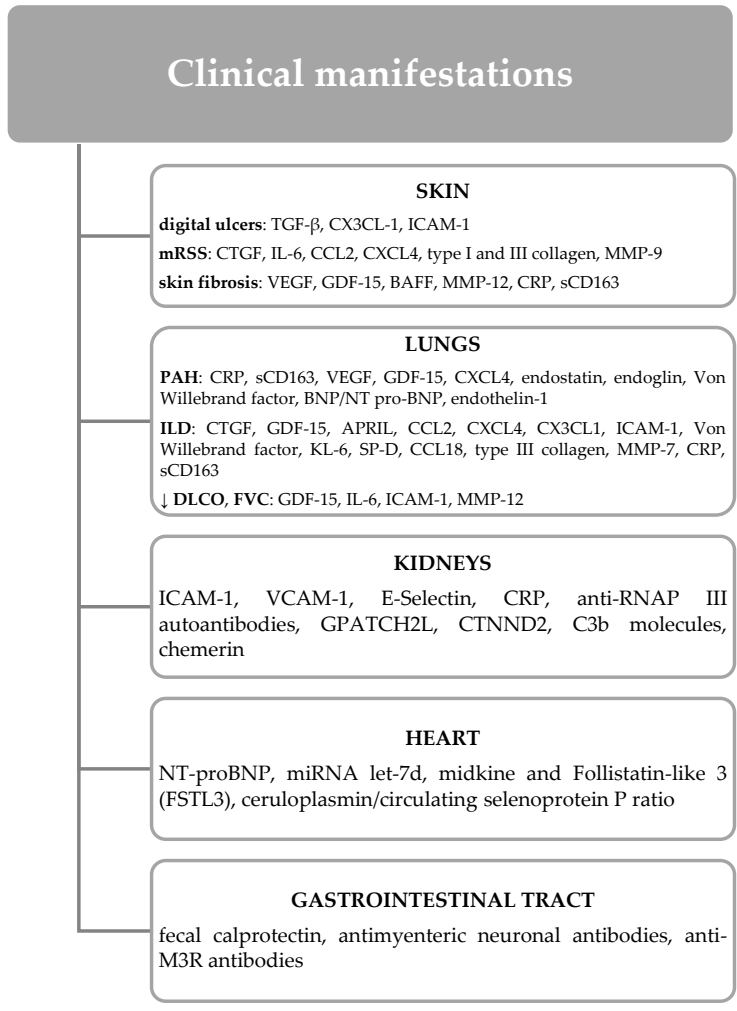

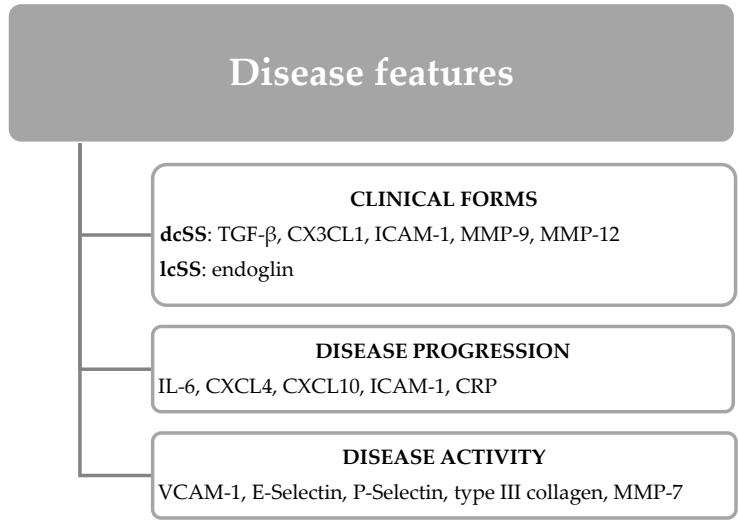

Figure 1. Potential biomarkers of organ involvement and disease features in SS. Key: TGF: transforming growth factor; GDF-15: growth differentiation factor 15; BAFF: B-cell-activating factor belonging to the tumor necrosis factor family; APRIL: a proliferation-inducing ligand; MMP: matrix metalloproteinases; BNP: brain natriuretic peptide; NT-proBNP: N-terminal-pro hormone BNP; CTG: connective tissue growth factor; mRSS: modified Rodnan total skin thickness score; ILD: interstitial lung disease; IL-6: interleukin 6; DLCO: diffusing capacity of carbon monoxide; PAH: pulmonary arterial hypertension; ICAM-1: intercellular adhesion molecule 1; dcSSc: diffuse cutaneous systemic sclerosis; VEGF: vascular endothelial growth factor; lcSSc: limited cutaneous systemic sclerosis; KL-6: krebs von den Lungen-6; SP-D: surfactant protein-D; CCL2: monocyte chemoattractant protein-1; CXCL4: platelet factor 4; VCAM-1: vascular cell adhesion molecule-1; CRP: C-reactive protein; sCD163: soluble CD163; anti-RNAP III antibodies: anti-RNA polymerase III antibodies; anti-M3R antibodies: antihuman muscarinic receptor M3 antibodies; miRNA let-7d: micro RNA let-7d; GPATCH2L: G-patch domain-containing protein 2-like; CTNND2: catenin delta 2.

Given the complex pathogenic mechanisms and the multitude of cells and cytokines, we will continue to focus on interleukin 6 (IL-6), which is considered to be one of the major fibrogenic cytokines along with interleukin 4 (IL-4) and transforming growth factor (TGF)- $\beta[3]$.

\section{IL-6: General Data}

IL-6 is part of a large family of cytokines, having important roles in regulating immunity, hematopoiesis, inflammation, and oncogenesis. In the past, depending on its biological effect, IL-6 had different names: B lymphocyte-stimulating factor 2 (BSF-2), hepatocytestimulating factor (HSF), or interferon- $\beta 2$ [8]. In 1989, it was found that all these molecules are identical, so it was renamed IL-6, a name used until today [9].

The biological effect of IL- 6 can be achieved by two signaling pathways: the classical pathway, which uses a membrane receptor, and the trans-signaling pathway, which involves the presence of a soluble IL-6 receptor. The classical signaling pathway involves 
the binding of IL-6 to the membrane receptor-IL-6R [10]. Normally, the expression of this receptor is decreased, being found in several cells, especially hepatocytes and some immune cells [11,12]. IL-6R has no intrinsic signaling capacity. The IL-6/IL-6R interaction induces the dimerization of an IL-6R signaling-related cytokine called gp130 [13-15]. Unlike IL-6R, this gp130 molecule is ubiquitously expressed and has an intrinsic signaling capacity. The IL-6/IL-6R complex bound to gp130 initiates cellular signaling via several intracellular or extracellular pathways [10,12,16]. Gp130-mediated activation of Janus kinase (Jak) family members and subsequent phosphorylation of specific tyrosine residues cause phosphorylation and dimerization of STAT (signal transducer and activator of transcription proteins) $[10,16]$. The latter determines the transcriptional activation of IL-6-dependent genes [16].

The alternative IL-6 trans-signaling pathway involves the presence of a soluble receptor (sIL-6R) [16-19]. This receptor is formed after cleavage of IL-6R by activated ADAM17 (Disintegrin Metalloproteases 17) and ADAM10 (Disintegrin Metalloproteases 10) [20,21]. Binding of IL-6 to sIL-6R and subsequently to gp130 IL-6/sIL-6R determines intracellular signaling, which is very similar to classical IL-6R signaling. In addition, sIL-6R has the advantage of binding circulating IL-6, thereby prolonging the half-life of IL-6 [22]. Moreover, sIL-6R participates in the interaction between leukocytes and vascular endothelium, causing the endothelial production of MCP-1 (monocyte chemoattractant protein-1), a key chemokine that regulates monocyte/macrophage infiltration of the vascular wall [23].

To limit the proinflammatory effects of IL-6, IL-6 signaling is regulated by several inhibitory molecules and processes. Inhibition of IL-6 signaling is important in order to limit inflammation and its side effects, such as extensive tissue damage. Thus, STAT3-dependent transcription is rapidly inactivated by the cytokine 3 signaling suppressor (SOCS3) [24-27]. IL-6-induced SOCS3 expression acts as a major negative feedback loop for IL-6 signaling. Another inhibitory mechanism, a soluble form of gp130 (sgp130), has been identified in patients' plasma [28,29]. sgp130 serves as a functional antagonist of IL-6 trans-signaling by binding to the IL-6/sIL-6R complex and preventing IL-6/IL-6R complex binding to the gp130 membrane molecule [30]. A third mechanism of inhibition of IL-6 signaling involves a STAT-3 inhibitor (PIAS3-Protein Inhibitor of Activated STAT 3) that blocks the interaction between phosphorylated STAT3 and cellular DNA and finally genetic transcription [31].

Figure 2 schematically shows these two intracellular signaling pathways of IL-6, and the main negative feedback loops that block the production of its biological effects (Figure 2).

IL-6 is a key cytokine in inflammation, having a systemic polymorphic pathway. Thereby, after the initial stage of inflammation and local production, IL-6 is transported through the blood vessels in the liver. Here, it determines the formation and increased secretion of acute phase proteins, such as C-reactive protein (CRP), serum amyloid A, fibrinogen, and hepcidin. On the other hand, IL-6 has an inhibitory effect on the secretion of fibronectin, albumin, and transferrin [32,33]. Due to the stimulatory effect of hepcidin formation, the iron transporter is blocked in the gut (ferroportin 1) [34]. Thus, the IL6-hepcidin axis is responsible for hyposideremia and anemia associated with chronic inflammation. In addition, IL-6 has the ability to promote zinc deposition in hepatocytes by increasing the expression of ZIP14-specific transporter. The regulation of ZIP14 by IL- 6 contributes to hepatic accumulation of zinc and to the decrease in the serum zinc concentration highlighted in inflammation $[32,35]$. 


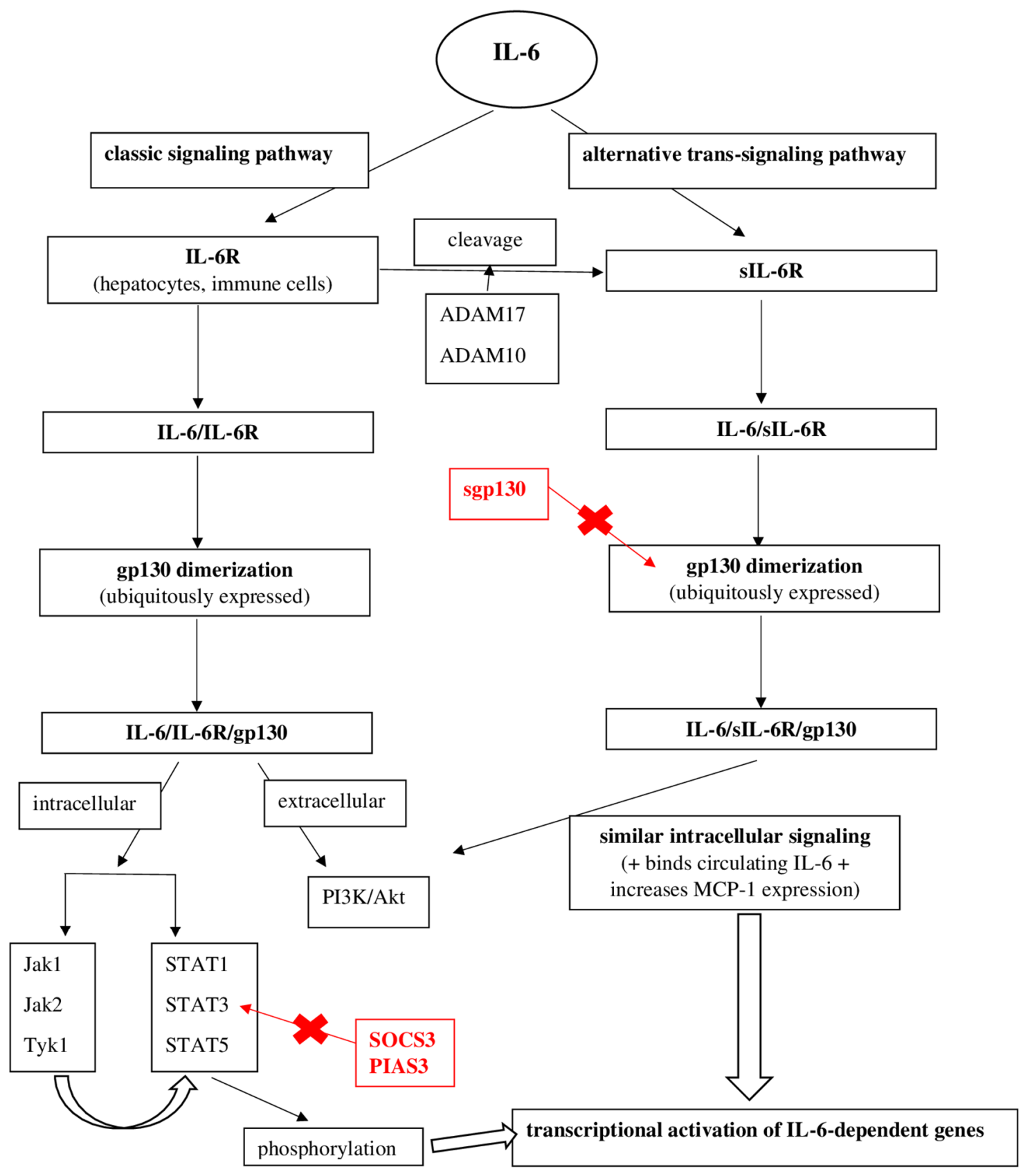

Figure 2. The intracellular signaling pathways of IL-6 and the main negative feedback loops that block the production of its biological effects. Key: IL-6: interleukin-6; IL-6R: interleukin-6 receptor; sIL-6R: soluble interleukin-6 receptor; gp130: glycoprotein 130; Jak: janus kinase; STAT: signal transducer and activator of transcription proteins; SOCS3: cytokine 3 signaling suppressor; PIAS3: protein inhibitor of activated STAT 3; ADAM: disintegrin metalloproteases; MCP: monocyte chemoattractant protein-1.

IL-6 plays an important role in the innate or adaptative immune response by stimulating CD4+ T cell differentiation [32]. Data from the literature support the indispensable role of the IL-6-TGF- $\beta$ axis in differentiating Th17 cells from naive T CD4+ cells [36]. Moreover, inhibition of regulatory $\mathrm{T}$ cell differentiation (Treg) occurs [37]. This Th17/Treg imbalance is responsible for disrupting immune tolerance, leading to chronic inflammatory autoimmune disorders [38]. IL-6 has the ability to stimulate follicular T helper cell differentiation and the production of IL-21, which is responsible for the synthesis of immunoglobulins (Ig), especially IgG4 [39]. IL-6 can induce CD8+ cell differentiation into cytotoxic T cells [40]. 
IL-6 also acts on B lymphocytes, activating and transforming them into plasma cells, thus promoting the production of autoantibodies and hypergammaglobulinemia [32].

IL-6 can have a direct effect on osteoblast precursors, blocking their differentiation and maturation [41]. IL-6 induces the secretion of matrix metalloproteinases (MMP-1, MMP-3, MMP-13) from chondrocytes and synovial cells. MMP-1 and MMP-13 are able to break type II collagen, and MMP-3 exerts its action on the extracellular matrix, fibronectin, and laminin [42]. In addition, elevated levels of IL-6 in bone marrow stromal cells stimulate the activator receptor of nuclear factor kappa-B ligand (RANKL), leading to osteoclast differentiation and activation [43].

The action of IL-6 is systemic, being a key element in the development and perpetuation of inflammation. IL-6 participates in the formation of a cytokine storm by activating immune cells and stimulating the secretion of new inflammatory mediators. Figure 3 shows the main cells on which IL-6 acts and the systemic effects it can have.

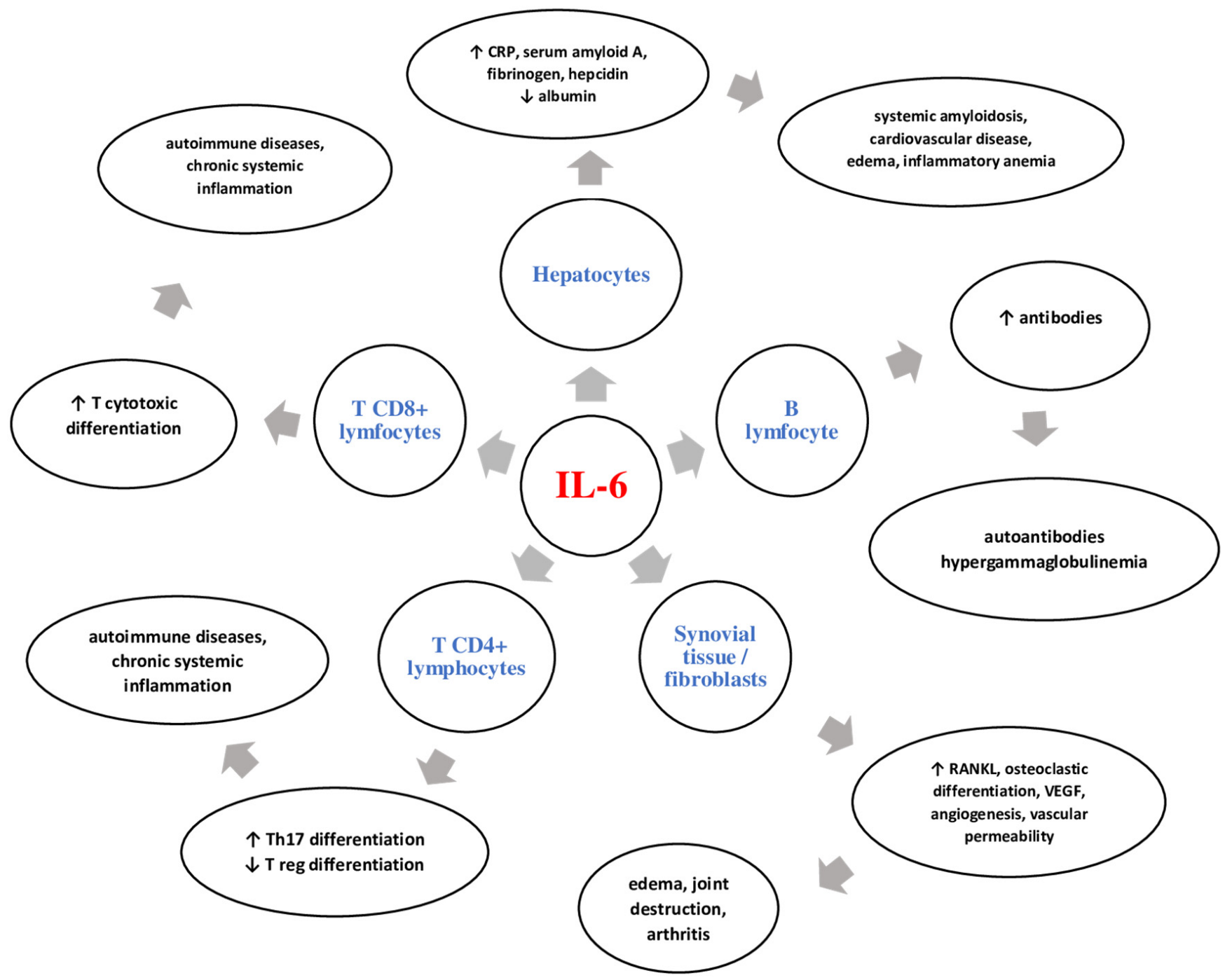

Figure 3. The action of IL-6 on various cells and its local and systemic manifestations. Key: IL-6: interleukin 6; CD: cluster of differentiation; CRP: C-reactive protein; RANKL: activator receptor of nuclear factor kappa-B ligand; VEGF: vascular endothelial growth factor; Treg: regulatory T cells.

\section{IL-6 in Systemic Sclerosis}

IL-6 has a particular role in the pathogenesis of SS, both in vascular damage and in the development of fibrosis. The increase in collagen production is achieved through different pathways, such as differentiation of myofibroblasts, inhibition of the secretion of 
matrix metalloproteinases with collagenolytic effect, and activation of fibroblasts [44]. The trans-signaling pathway is mandatory for collagen production and for the appearance of fibrotic changes due to the presence of sIL-6R [45]. This is supported by data from murine studies. The occurrence of an SS-like condition with pulmonary fibrosis and skin thickening was determined by IL-6 signaling [46]. On the other hand, a decrease in pulmonary fibrosis and inflammation was observed in IL-6-deficient mice [47].

Genetic susceptibility plays an important role in the pathogenesis of SS; therefore, the polymorphism of the IL-6 gene has been studied in various clinical trials. The most studied gene is $r s 1800795$ (also known as $-174 \mathrm{C} / \mathrm{G}$ ), with $\mathrm{G}$ alleles being associated with increased IL-6 levels [48,49]. An analysis of -174 C/G IL-6 polymorphism in a cohort of $102 \mathrm{SS}$ patients revealed increased IL-6 gene expression in G-allele carriers. This genetic polymorphism of IL-6 was correlated only with the presence of gastrointestinal manifestations, not with skin and lung damage [50]. Other data obtained after studying 20 cases with SS support the link between IL-6 polymorphism, especially the homozygous GG form, and an active and disabling disease [51].

\subsection{IL-6 and SS Features}

Elevated serum and skin levels of IL-6 have been highlighted in both early and late stages of SS [52,53]. In the early stages, IL-6 participates in vascular endothelial activation and apoptosis [54], leading to the release of damage-associated molecular patterns (DAMPs), which maintain inflammation and autoimmunity [55].

Numerous data support this increase in IL-6 levels, both in the tissues and in the serum of patients with SS. Feghali's study showed elevated levels of IL-6 in the skin tissue supernatant cultures of SS patients, even 30 times higher than the control arm [56]. By culturing peripheral blood mononuclear cells isolated from cases of SS with type I collagen, Gurram highlighted an increased level of IL-6 in the supernatant, which shows that IL- 6 can be highly secreted by other unaffected tissues [57]. Various methods for measuring serum IL-6 levels have been used over time, such as bioassays and ELISA (enzyme-linked immunosorbent assay). Needleman, using a bioassay method, found detectable concentrations of IL-6 in the serum of SS patients [58]. The ELISA method provided important data on elevated IL-6 levels in these patients, levels that correlated with the degree of skin damage quantified by the cutaneous score $[59,60]$.

It seems that the concentration of IL-6 depends on the duration and form of SS. Thus, a study that included 55 SS patients analyzed the levels of IL-6, sIL-6R, and sgp130 according to the form of the disease. Patients were divided into 4 arms: 12 having an lcSS (limited cutaneous SS) and an early form of disease (less than 3 years from disease onset), 22 with lcSS and a late form (over 3 years from disease onset), 9 cases of an early dcSS form (diffuse cutaneous SS), and 12 cases of a late dcSS form [61]. Following the statistical analysis, the authors found significantly higher levels of IL-6 in the early SS form compared to the control arm, with high levels found especially in patients with pulmonary fibrosis. IL-6 was inversely correlated with vital lung capacity (VPC). IL-6 levels have also been associated with acute phase reactants and A and G immunoglobulin levels [61]. Regarding sIL-6R, elevated levels were observed in a limited SS form compared to the control. For sgp130, no statistically significant data were highlighted [61].

The fact that there is a different secretion of cytokines depending on the stage of the disease has been demonstrated by clinical trials. Thus, Matsushita showed a significant increase in IL- 6 and IL-10 in the early stages of the disease, and a significant numerical decrease after 6 years of evolution. Opposite data have been described for IL-12, whose values were decreased in the early stages and more than 15 times increased in the disease with a 6-year evolution [62]. The level of IL-6 has been shown to be inversely proportional to that of IL-13, with early-stage patients having a high IL-6 and low IL-13 amount [63]. 


\subsection{IL-6 and Skin Manifestations}

IL-6 plays an important role in the development of fibrotic changes by mediating the transformation of fibroblasts into myofibroblasts, with the latter producing an excessive amount of collagen that infiltrates various organs and tissues, including the heart [64]. Myofibroblasts were found in the dermis in the early and progressive SS forms, with histological analysis indicating their disappearance in late (atrophic) forms of the disease [65]. Furthermore, a study that included a model of bleomycin SS model mice showed a numerical decrease in myofibroblasts after administration of anti-IL-6R antibodies [66]. The same data were highlighted by Kawaguchi, who performed cultures of cutaneous fibroblasts isolated from SS patients and found a high level of procollagen type I in the supernatant. After incubating these cultures with anti-IL-6R antibodies, a numerical decrease in collagen fibers was observed [67].

\subsection{IL-6 and Lung Manifestations}

The involvement of IL-6 in fibrotic lesions has been proven by clinical trials, especially in lung damage. Pulmonary fibrosis in SS has a multifactorial etiopathogenesis that includes both infiltration with inflammatory cells at the alveolar, peribronchiolar, and interstitium levels, and an intense and aberrant proliferation of fibroblasts that cause the deposition of fibronectin, type I and III collagen fibers, and tenascin $[68,69]$.

Regarding IL-6, Crestani's data included the analysis of cultures of alveolar macrophages obtained after bronchoalveolar lavage in SS patients. In the supernatant, the researchers found an increased level of IL-6 compared to the control group [70]. Other recently published data point to the same increased level of IL-6 in cases of SS with advanced pulmonary fibrosis due to the perpetuation of chronic inflammation, inhibition of the secretion of metalloproteinases, and increased collagen fiber synthesis [71]. On the other hand, another important pathogenic mechanism involved in the development of pulmonary fibrosis is the enhancement of IL- 6 trans-signaling via ADAM-17 by activated macrophages, which increases the extracellular matrix deposits and the proliferation of fibroblasts [72]. In this situation, it seems that inhibition of the IL- 6 trans-signaling pathway may be a useful therapeutic approach [71,72].

IL-6 levels, especially in early SS with mild forms of pulmonary fibrosis, appear to have a prognostic value for impaired lung function and increased mortality. This is supported by the analysis of 74 cases of SS associated with pulmonary fibrosis. An IL-6 value of more than $7.67 \mathrm{pg} / \mathrm{mL}$ can be considered a predictor of decreased DLCO (diffusing capacity of lung for carbon monoxide) and FVC (forced vital capacity) in the first year. It also correlates with an increase in mortality in the first 30 months of the disease [73]. Other data obtained after analyzing a cohort of 68 SS patients support the prognostic value of IL-6, with increased values being correlated with the extension of skin involvement at the 3-year follow-up, the development of pulmonary fibrosis, and worse long-term survival. Therefore, IL- 6 can be considered a predictive marker for disease progression [60,74]. Furthermore, IL-6 levels may be useful in stratifying patients regarding disease activity and survival outcome [75-77].

\subsection{IL-6 and Cardiovascular Manifestations}

IL-6 plays an important role in the cardiovascular involvement of SS. In this regard, an analysis of 20 cases with SS showed positive correlations between the level of IL-6 and the disease duration; EUSTAR (European Scleroderma Study Group) activity score; musculoskeletal, vascular, and respiratory status; and pressure peak in the pulmonary artery [78]. Other positive associations were noted with the pulmonary fibrosis score quantified by HRCT (high-resolution computer tomograph). Negative correlations were scored between IL-6, DLCO, the 6-min walk distance, and right ventricle systolic function parameters [78].

Furthermore, IL-6 may be considered a marker for pulmonary arterial hypertension (PAH) [79]. PAH mainly occurs in the limited form of the disease [80] and is closely related 
to the proliferation of endothelial cells and the formation of extracellular matrix deposits that cause intimate thickening of the capillaries and pulmonary arterioles [81]. Systemic inflammation, represented by IL-6, plays an important role in the development of PAH due to perivascular inflammatory cell infiltrates [81]. The risk of death is higher compared to idiopathic PAH [82,83], being linked to an accentuated intimal hyperplasia, fewer plexiform lesions, and the involvement of pulmonary veins $[81,84]$.

\subsection{IL-6 and Gastrointestinal Manifestations}

In addition to lung damage, $90 \%$ of SS patients also have gastrointestinal involvement (GI) [85], which is the 3rd leading cause of death [86]. GI impairment is associated with a marked disability and a decreased quality of life in SS patients, leading to reduced survival [86,87]. IL-6 gene polymorphism increases disease susceptibility, being associated with different clinical manifestations [49]. Zekovic's study, which included 102 SS cases, analyzed the correlations between IL-6 expression and GI manifestations and the presence of a specific disease genotype / phenotype [50]. The results showed that the presence of the C-allele correlates with increased IL-6 gene expression and with GI manifestations, with the most common being abdominal distension and worsening of the GI score (UCLA GIT 2.0) [50].

The pathogenic mechanisms involved in the occurrence of GI manifestations are complex and include concentric intimate thickening and deposition of collagen and mucoid molecules [88], adventitia fibrosis [89], autonomic dysfunction affecting neuromuscular junction, smooth muscle atrophy [90,91], presence of antimyenteric neuronal antibodies, anti-U3 RNP and anti-muscarinic-3 receptor antibodies [92-95], and small intestinal bacterial overgrowth serologically expressed by an increased fecal calprotectin [96]. The clinical manifestations are polymorphic and may include the entire GI tract, with patients complaining of dysphagia, intestinal transit disorders, fecal incontinence, pseudo-obstruction, or having clinical signs of malabsorption [97].

\subsection{IL-6 and Kidney Manifestations}

SS kidney disease has an incidence of up to 10\% [98] and is associated with increased long-term mortality [99], with scleroderma renal crisis (SRC) being a medical emergency. Genetic predisposition, autoimmune mechanisms, inflammatory cascade, and vasculopathy are the main mechanisms involved in the pathogenesis of SRC. An increased expression of two proteins: GPATCH2L and CTNND2, was highlighted in a recent study that analyzed kidney biopsy pieces in SS patients, suggesting the involvement of genetic susceptibility in the development of the disease [100]. Among autoantibodies, anti-RNA polymerase III antibodies are associated with renal impairment and have a prognostic value [101]. The main inflammatory markers involved in kidney damage are interleukins (IL-2r, IL-6, IL-10, IL-18) and chemokines, such as MCP-1 (monocyte chemoattractant protein-1) [102,103]. Vasculopathy refers to intimal proliferation and thickening of the renal arcuate and interlobular arteries, which causes activation of the renin-angiotensin system [104,105].

Clinically, patients present with rapidly progressive acute renal failure, malignant hypertension that may be complicated by hypertensive encephalopathy and retinopathy, pulmonary edema, or seizures. Microangiopathic hemolytic anemia, cardiac arrhythmias, myocarditis, and fever may also occur [106,107].

All of these systemic harmful effects of IL-6 are shown schematically in Figure 4. 


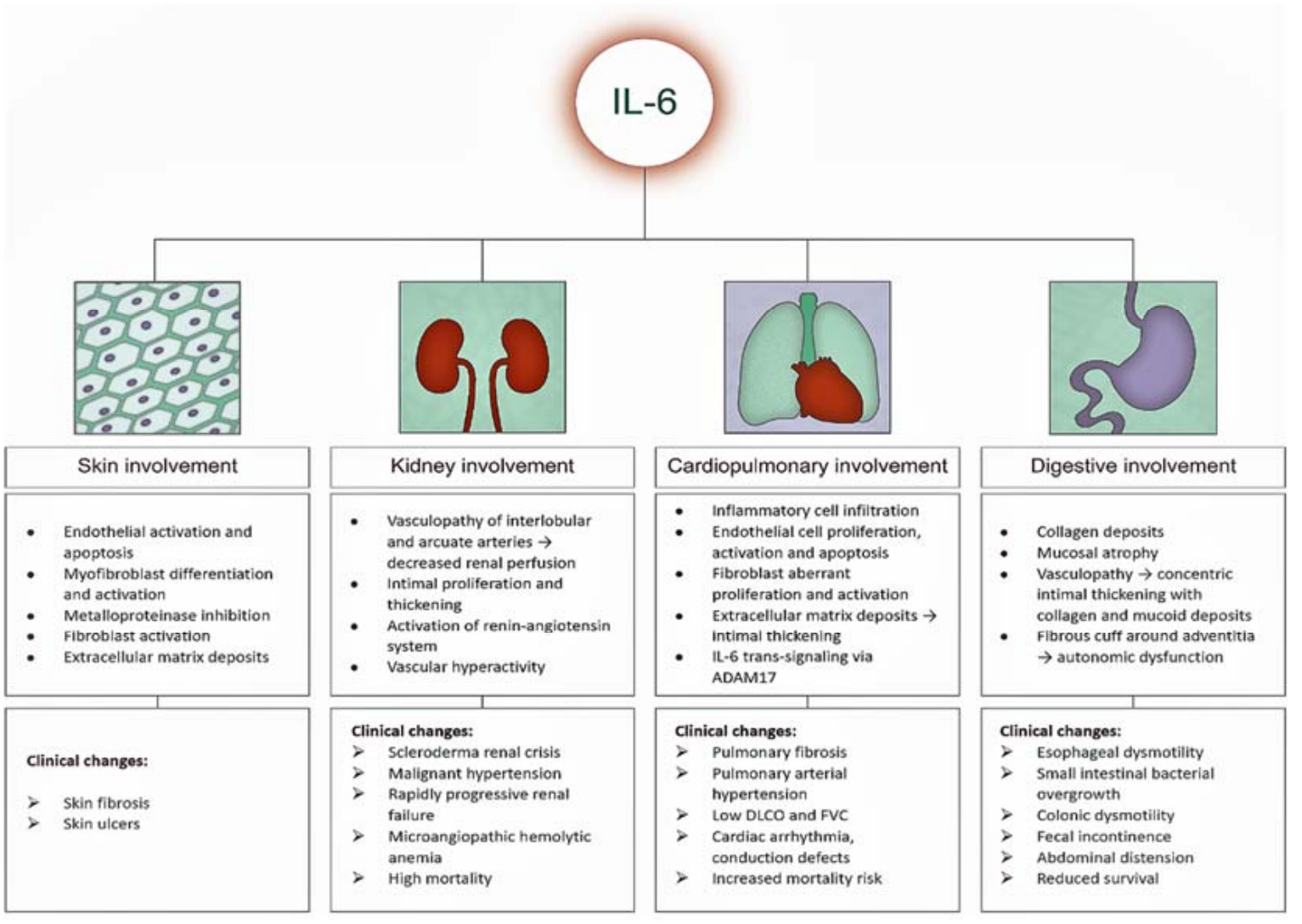

Figure 4. Systemic harmful effects of IL-6 on the skin, cardiopulmonary, gastrointestinal and renal system. Key: IL-6, interleukin-6; ADAM17: disintegrin metalloproteases 17; PAH: pulmonary arterial hypertension; DLCO: diffusing capacity of lung for carbon monoxide; FVC: forced vital capacity.

\section{Targeting IL-6 in Systemic Sclerosis}

Given the above data, we can sustain that IL-6 can be considered a key cytokine in the development and evolution of SS. For these reasons, anti-IL-6 therapy with Tocilizumab is a new hope for SS patients, with data from clinical trials supporting both cutaneous and pulmonary improvement. Tocilizumab is a humanized monoclonal antibody that inhibits IL-6 binding to mIL-6R (membrane IL-6R) and sIL-6R and prevents its pro-inflammatory and fibrotic effects [108]. In addition to SS, this beneficial effect has been shown in a variety of conditions, such as rheumatoid arthritis, juvenile idiopathic arthritis, Takayasu's arteritis, Still's adult disease, giant cell arteritis, and Castleman's disease [109-113].

The benefits of Tocilizumab in SS have been highlighted in phase 2 and 3 studies since 2016. The FaSScinated study is a randomized, double-blind, placebo-controlled phase 2 trial that included 87 SS patients from 35 sites [114]. Randomization was 1:1, with 43 cases in the SS group for whom the onset of the disease was less than 5 years and who received subcutaneous Tocilizumab $162 \mathrm{mg}$ weekly versus a placebo arm, which included 44 patients. No patient had been on background immunosuppressive therapy. The primary endpoint was an improvement in the modified RODNAN skin score (mRSS) at 24 weeks, which was not achieved, but the data showed a cutaneous improvement after Tocilizumab administration (mRSS decrease with 3.92 for Tocilizumab vs. 1.22 for placebo, $p=0.0915$ ). A more significant skin improvement was seen after 48 weeks with Tocilizumab, but this still did not reach statistical significance (mRSS decrease with 6.33 for Tocilizumab vs. 2.77 for placebo, $p=0.0579$ ). Data regarding lung damage were promising, showing a significantly smaller decrease in FVC for Tocilizumab at week 48 compared with the placebo $(p=0.0373)$. Regarding fatigue, itching, clinician global disease severity, and disability, there were no differences between the two groups. The safety of Tocilizumab was comparable to the placebo (42 vs. 40 ), but more severe infections were reported in the active arm (7 vs. 2), with 
1 death. The authors concluded that, although the skin primary endpoint was not achieved, the decrease in lung involvement was significant, thus opening new research perspectives.

Two years later, Khanna published the results of a phase 3 study (focuSSced study) that focused on Tocilizumab's effectiveness on skin and lung fibrosis, also including data regarding disability, treatment failure, and safety [115]. The randomized, double-blind, placebo-controlled trial included 210 patients with an early dcSS ( $<5$ years) without background immunosuppressive treatment. Randomization was 1: 1, with 104 cases receiving subcutaneous Tocilizumab $162 \mathrm{mg}$ weekly and 106 on placebo. The primary endpoint was an improvement in the mRRS skin score at week 48 , which was not achieved $(p=0.10)$. Secondary objectives included the change in the predicted percentage of FVC, patient- and physician-reported outcomes, and time to treatment failure at week 48 . Significant data were obtained for the predicted percentage of FVC, with Tocilizumab being effective in preserving lung functionality $(p=0.002)$. The results on disability and the overall physician and patient assessment of the disease were not significant. The Tocilizumab safety profile was good, with the most common side effects being infections.

Other recently published data support Tocilizumab's beneficial effect on skin fibrosis. A study on the effect of IL-6 blockade on the molecular, genomic, and functional characteristics of cultured fibroblasts from skin biopsies of SS patients was performed [116]. The analysis included 12 patients treated with Tocilizumab or placebo for 24 weeks. An activated molecular and functional phenotype was maintained after 24 weeks with placebo. In contrast, fibroblasts in Tocilizumab patient cultures underwent beneficial changes, such as decreased migration, proliferation and contraction, and low collagen fiber production. Furthermore, by analyzing the genetic profile dominated by genes that promote fibrosis (TGF $\beta$-regulated genes, COL1A1), it was found that Tocilizumab can induce normalization of the genetic phenotype, thereby improving skin thickening [116]. The findings of this analysis were promising and highlighted the dual role of IL-6 blockade in inflammation and fibrosis.

Other data on the improvement of cutaneous fibrosis with Tocilizumab come from smaller studies, even from case reports and case series, considering the low incidence of the disease. Shima followed 2 patients with SS refractory to conventional therapies who received Tocilizumab $8 \mathrm{mg} / \mathrm{kg} /$ month for 6 months. Skin damage was assessed by both the mRRS score and with a Vesmeter device, which measures viscosity, elasticity, and skin thickening [117]. Tocilizumab therapy resulted in skin softening quantified by both scores. Another study by Shima included seven SS cases; its main purpose was to investigate the cutaneous efficacy of Tocilizumab quantified by the mRRS score and to analyze the factors that contribute to treatment response [63]. Skin improvement was evident after Tocilizumab therapy, but the data were not statistically consistent. Moreover, the decrease in the mRSS score was higher in cases with a significant inflammatory syndrome (quantified by CRP) and shorter disease duration. Negative correlations were found between the mRRS score and chemokine CCL-5 and IL-13 levels.

In addition to improving skin fibrosis, Tocilizumab appears to be effective in osteoarticular changes. Zacay et al. administered Tocilizumab in 16 cases of SS without clinical response to other immunosuppressants. All patients had musculoskeletal involvement. Twelve patients with arthritis / arthralgia showed a significant improvement after treatment. One case of myalgia improved, and three out of four with myositis showed normalization of muscle enzymes after Tocilizumab [118]. In addition, the authors found a significant improvement in the mRSS skin score, which decreased by 11 points, and an improvement in lung capacity in $46 \%$ of cases. All these favorable responses were mainly recorded in patients with an early disease. The same positive effect on musculoskeletal manifestations is supported by EUSTAR (The European Scleroderma Trials and Research group), which analyzed the response to Tocilizumab and abatacept in a cohort of 27 SS cases. All patients with polyarthritis significantly improved after 5 months of therapy. However, the mRSS score did not show a statistically significant decrease [119]. In the two cases presented by Shima [117], one of the patients had a significantly limited range of joint motion, which 
improved after Tocilizumab therapy, thus strengthening the efficacy of the IL-6 inhibitor on joint involvement and supporting its inclusion in the SS treatment algorithm [120].

Regarding lung damage, one of the most important complications of the disease and the leading cause of death, Tocilizumab therapy is a recently approved solution linked to decreased lung worsening and maintenance of pulmonary function. The results of the extension of the phase 3 focuSSced study support this pulmonary improvement after switching from placebo to Tocilizumab [121]. Thus, 78 patients in the placebo arm switched to Tocilizumab. After 2 years of treatment, $50 \%$ of them maintained a constant level of FVC. Only 3\% (2 cases) developed an increase in pulmonary fibrosis quantified by a decrease in FVC of over $10 \%$. All of these patients showed not only maintenance of lung capacity, but even an improvement in FVC of $0.6 \%$ after 2 years. The results were similar to those in patients treated with Tocilizumab from the beginning. Moreover, the 48 -week extension of the faSScinate study strengthened the effect of Tocilizumab therapy in stabilizing lung function. In addition, there was a further improvement in the mRSS score at week 96 [122].

Recently, in 2021, a post hoc analysis of the focuSSced trial was published, which aimed to analyze the preservation of lung function in 136 cases of SS and intestinal lung disease. As a novelty, stratification of patients was conducted according to the degree of pulmonary fibrosis: mild (5-10\%), moderate (10-20\%), and severe $(>20 \%)$ [123]. The included patients had an early SS with progressive skin disease and pulmonary fibrosis, so they were in the immunoinflammatory phase of the disease. Moderate and severe fibrotic lung impairment had an increased incidence of $77 \%$. The authors identified inverse correlations between the degree of pulmonary fibrosis and the predicted FVC percentage. FVC stabilization was similar in all study arms regardless of fibrosis and was significantly more important for Tocilizumab compared to the placebo $(-0.1 \%$ Tocilizumab vs. $-6.3 \%$ placebo, $p<0.0001)$. Because Tocilizumab's favorable pulmonary effects were observed in the early fibrotic phase of SS, the authors hypothesized that a window of therapeutic opportunity exists during this stage.

Tocilizumab may be considered as a rescue therapy in non-responsive cases. Narvaez included in an analysis nine cases of progressive SS with interstitial lung disease refractory to corticosteroid therapy (low and medium doses), rituximab, and other immunosuppressants (cyclophosphamide, azathioprine, mycophenolate mofetil). Patients received Tocilizumab (both intravenously and subcutaneously) in combination with mycophenolate mofetil for 6 months; prednisone below $5 \mathrm{mg} /$ daily was used in 7 cases. The results regarding lung damage were promising, with $44 \%$ of patients experiencing both stabilization and an improvement in lung capacity quantified by FVC, DLCO, and the 6-min walking test [124].

Another recent analysis, reinforced by real-world data, indicated again the beneficial effect of Tocilizumab on skin and lung damage, its long-term safety, and an improvement in patient-reported outcomes. Thus, Khanna's study of 82 SS cases showed an improvement in mRSS and FVC and a good safety profile after 96 weeks of Tocilizumab administration [125]. Panopoulos' analysis of 21 SS patients receiving subcutaneous Tocilizumab for 1 year showed the same efficacy data on the mRSS score and polyarticular impairment, also providing stabilization of lung damage and an improvement in patient-reported outcomes [126].

The benefit of Tocilizumab therapy in SS heart disease has been less studied so far. Due to repeated lesions of ischemia and reperfusion, histological changes in band-like necrosis, and diffuse macular fibrosis, SS can be considered an independent risk factor for cardiovascular disease $[127,128]$. This year, the case of a young patient diagnosed with lcSS in 2015 who developed ventricular extrasystoles and changes in cardiac reperfusion highlighted on an interventricular septum biopsy test was published. Mycophenolate mofetil $2 \mathrm{~g}$ daily was administered for 3 months, but the heart condition worsened. Intravenous treatment with Tocilizumab $8 \mathrm{mg} / \mathrm{kg} / \mathrm{monthly}$ was initiated with favorable results regarding clinical symptoms and reperfusion defects [129]. 
Finally, there are data indicating the favorable effect of Tocilizumab on SS juvenile forms (JSS). The first published study of the efficacy of Tocilizumab in JSS was published last year and included nine JSS cases on anti-IL-6R therapy in combination with methotrexate, mycophenolate mofetil, or corticosteroids. Patients mainly had pulmonary and gastrointestinal manifestations [130]. After a mean follow-up of 24 months, statistically significant data were recorded for skin damage (decreased mRSS), lung function (increased DLCO), global patient assessment (PGA), and Juvenile Systemic Sclerosis Severity (J4S), which improved.

All these data presented above regarding the clinical efficacy of Tocilizumab therapy in SS patients are summarized in Table 1.

Table 1. Data regarding the clinical efficacy of Tocilizumab therapy in SS patients.

\begin{tabular}{|c|c|c|c|c|}
\hline Author & Number of Patients & $\begin{array}{c}\text { Clinical and Paraclinical } \\
\text { Parameters }\end{array}$ & $\begin{array}{l}\text { Follow-Up } \\
\text { Period }\end{array}$ & Results \\
\hline $\begin{array}{l}\text { Shima et al., } 2010 \\
{[117]}\end{array}$ & 2 & mRSS & 6 months & $\begin{array}{l}\text { - } \quad \text { skin thickening improvement (mRSS } \\
\text { decrease) }\end{array}$ \\
\hline $\begin{array}{l}\text { Elhai et al., } 2013 \\
\text { [119] }\end{array}$ & 27 & $\begin{array}{l}\text { Polyarthritis } \\
\text { Myopathy } \\
\text { mRSS }\end{array}$ & 5 months & $\begin{array}{l}\text { - } \quad \begin{array}{l}\text { joint/muscle damage improvement } \\
\text { skin thickening improvement } \\
\text { (mRSS decrease) }\end{array} \\
\end{array}$ \\
\hline $\begin{array}{l}\text { Khanna et al., } 2016 \\
\text { [114] }\end{array}$ & 87 & mRSS & 6 months & $\begin{array}{l}\text { - } \quad \text { skin thickening improvement } \\
\text { (mRSS decrease) } \\
\text { - } \quad \text { smaller decrease in FVC }\end{array}$ \\
\hline Khanna et al., 2017 [122] & 78 & $\begin{array}{c}\text { mRSS } \\
\text { FVC }\end{array}$ & 24 months & $\begin{array}{l}\text { - } \quad \text { skin thickening improvement } \\
\text { (mRSS decrease) } \\
\text { - } \quad \text { lung function stabilization }\end{array}$ \\
\hline Khanna et al., 2018 [115] & 210 & $\begin{array}{c}\text { mRSS } \\
\text { FVC }\end{array}$ & 12 months & $\begin{array}{l}\text { - } \quad \begin{array}{l}\text { skin thickening improvement } \\
\text { (mRSS decrease) }\end{array} \\
\text { - } \quad \text { lung function stabilization }\end{array}$ \\
\hline $\begin{array}{l}\text { Denton et al., } 2018 \\
\text { [116] }\end{array}$ & 12 & mRSS & 6 months & $\begin{array}{l}\text { - } \quad \text { skin thickening improvement } \\
\text { (mRSS decrease) } \\
\text { decreased skin collagen fiber } \\
\text { production }\end{array}$ \\
\hline $\begin{array}{l}\text { Zacay et al., } 2018 \\
{[118]}\end{array}$ & 16 & $\begin{array}{l}\text { Arthritis/arthralgia } \\
\text { Myalgia/myositis } \\
\text { FVC } \\
\text { mRSS }\end{array}$ & 8 months & $\begin{array}{l}\text { - } \\
\text { significant improvement in } \\
\text { arthritis/arthralgia } \\
\text { muscle enzymes normalization } \\
\text { skin thickening improvement } \\
\text { (mRSS decrease) } \\
\text { lung capacity improvement } \\
\text { (FVC increase) }\end{array}$ \\
\hline $\begin{array}{l}\text { Shima et al., } 2019 \\
\text { [63] }\end{array}$ & 7 & mRSS & 6 months & $\begin{array}{l}\text { - skin thickening improvement (mRSS } \\
\text { decrease) especially in cases with } \\
\text { significant inflammatory syndrome } \\
\text { and short disease duration }\end{array}$ \\
\hline Narvaez et al., 2019 [124] & 9 & $\begin{array}{c}\text { FVC } \\
\text { DLCO } \\
6 \text { min walking test }\end{array}$ & 12 months & $\begin{array}{l}\text { - lung function stabilization and } \\
\text { improvement (FVC increase) in cases } \\
\text { refractory to corticosteroids or other } \\
\text { immunosuppressants }\end{array}$ \\
\hline $\begin{array}{l}\text { Khanna et al. } 2020 \\
\text { [121] }\end{array}$ & 78 & FVC & 24 months & $\begin{array}{l}\text { - lung function stabilization/ } \\
\text { improvement (FVC increase) }\end{array}$ \\
\hline $\begin{array}{l}\text { Roofeh et al., } 2021 \\
\text { [123] }\end{array}$ & 136 & FVC & 12 months & $\begin{array}{l}\text { lung function preservation according } \\
\text { to the degree of pulmonary fibrosis }\end{array}$ \\
\hline Khanna et al., 2021 [125] & 82 & $\begin{array}{l}\text { mRSS } \\
\text { FVC }\end{array}$ & 24 months & $\begin{array}{ll}\text { - } & \text { skin thickening improvement } \\
\text { (mRSS decrease) } \\
\text { - } \quad \text { lung function improvement } \\
\text { (FVC increase) }\end{array}$ \\
\hline Adrovic et al., 2021 [130] & 9 & $\begin{array}{l}\text { Juvenile SS } \\
\text { mRSS } \\
\text { DLCO }\end{array}$ & 24 months & $\begin{array}{ll}\text { - } & \text { skin thickening improvement (mRSS } \\
\text { decrease) } \\
\text { lung function improvement (DLCO } \\
\text { increase) }\end{array}$ \\
\hline Panopoulos et al., 2022 [126] & 21 & $\begin{array}{l}\text { mRSS } \\
\text { Polyarthritis } \\
\text { FVC } \\
\text { PROs }\end{array}$ & 12 months & $\begin{array}{ll}\text { - } & \text { skin thickening improvement } \\
\text { (mRSS decrease) } \\
\text { - } \quad \text { lung function stabilization } \\
\text { - } \quad \text { joint damage improvement (Disease } \\
\text { Activity Score 28 decrease) } \\
\text { improving patients' quality of life }\end{array}$ \\
\hline
\end{tabular}

Key: mRSS: modified RODNAN skin score; DLCO: diffusing capacity of lung for carbon monoxide; FVC: forced vital capacity; PROs: patient-reported outcomes. 


\section{Conclusions}

Although we have a rich therapeutic arsenal, SS remains a serious condition that involves a multidisciplinary approach and targeted therapies. The pathogenesis of the disease is complex and multifactorial, and is still incompletely known. IL-6 has an important role in both vasculopathy and fibrosis and is associated with various clinical manifestations. Blocking IL-6R with Tocilizumab results in many clinical and biological benefits due to its anti-inflammatory and anti-fibrotic effects. Recent studies have opened the way for Tocilizumab in SS, supporting its efficacy and safety.

Author Contributions: Conceptualization, A.C. and E.R.; methodology, A.C. and E.R.; software, A.M.B.; validation, E.R.; formal analysis, L.A.M. and E.R.; Investigation, I.B., P.R. and A.M.B.; resources, A.C., E.R., L.A.M. and A.M.B.; data curation, A.M.B. and E.R.; writing - original draft preparation, A.C.; writing - review and editing, A.C. and A.M.B.; visualization, E.R. and L.A.M.; supervision, E.R.; project administration, E.R.; funding acquisition, A.C. All authors conceived the article, co-wrote the final manuscript, and reviewed the literature. All authors have read and agreed to the published version of the manuscript.

Funding: This research received no external funding.

Institutional Review Board Statement: Not applicable.

Informed Consent Statement: Not applicable.

Data Availability Statement: Not applicable.

Conflicts of Interest: The authors declare no conflict of interests.

\section{References}

1. Allanore, Y.; Simms, R.; Distler, O.; Trojanowska, M.; Pope, J.; Denton, C.P.; Varga, J. Systemic sclerosis. Nat. Rev. Dis. Prim. 2015, 1, 15002. [CrossRef] [PubMed]

2. $\quad$ Denton, C.P.; Khanna, D. Systemic sclerosis. Lancet 2017, 390, 1685-1699. [CrossRef]

3. Brown, M.; O'Reilly, S. The immunopathogenesis of fibrosis in systemic sclerosis. Clin. Exp. Immunol. 2019, 195, $310-321$. [CrossRef] [PubMed]

4. Asano, Y.; Sato, S. Vasculopathy in scleroderma. Semin. Immunopathol. 2015, 37, 489-500. [CrossRef] [PubMed]

5. Brembilla, N.C.; Chizzolini, C. T cell abnormalities in systemic sclerosis with a focus on Th17 cells. Eur. Cytokine Netw. 2012, 23, 128-139. [CrossRef] [PubMed]

6. Cossu, M.; van Bon, L.; Nierkens, S.; Bellocchi, C.; Santaniello, A.; Dolstra, H.; Beretta, L.; Radstake, T.R. The magnitude of cytokine production by stimulated $\mathrm{CD} 56^{+}$cells is associated with early stages of systemic sclerosis. Clin. Immunol. 2016, 173, 76-80. [CrossRef]

7. Utsunomiya, A.; Oyama, N.; Hasegawa, M. Potential Biomarkers in Systemic Sclerosis: A Literature Review and Update. J. Clin. Med. 2020, 9, 3388. [CrossRef]

8. Kishimoto, T. Factors Affecting B-Cell Growth and Differentiation. Annu. Rev. Immunol. 1985, 3, 133-157. [CrossRef]

9. Kishimoto, T. The biology of interleukin-6. Blood 1989, 74, 1-10. [CrossRef]

10. Hunter, C.A.; Jones, S.A. IL-6 as a keystone cytokine in health and disease. Nat. Immunol. 2015, 16, 448-457. [CrossRef]

11. Chalaris, A.; Garbers, C.; Rabe, B.; Rose-John, S.; Scheller, J. The soluble Interleukin 6 receptor: Generation and role in inflammation and cancer. Eur. J. Cell Biol. 2011, 90, 484-494. [CrossRef] [PubMed]

12. Mihara, M.; Hashizume, M.; Yoshida, H.; Suzuki, M.; Shiina, M. IL-6/IL-6 receptor system and its role in physiological and pathological conditions. Clin. Sci. 2012, 122, 143-159. [CrossRef] [PubMed]

13. Saito, M.; Yoshida, K.; Hibi, M.; Taga, T.; Kishimoto, T. Molecular cloning of a murine IL-6 receptor-associated signal trans-ducer, gp130, and its regulated expression in vivo. J. Immunol. 1992, 148, 4066-4071.

14. Demyanets, S.; Huber, K.; Wojta, J. Vascular effects of glycoprotein130 ligands-Part II: Biomarkers and therapeutic targets. Vasc. Pharmacol. 2012, 57, 29-40. [CrossRef]

15. Klouche, M.; Bhakdi, S.; Hemmes, M.; Rose-John, S. Novel path to activation of vascular smooth muscle cells: Up-regulation of gp130 creates an autocrine activation loop by IL-6 and its soluble receptor. J. Immunol. 1999, 163, 4583-4589.

16. Ernst, M.; Jenkins, B.J. Acquiring signalling specificity from the cytokine receptor gp130. Trends Genet. 2004, 20, 23-32. [CrossRef]

17. Schöbitz, B.; Pezeshki, G.; Pohl, T.; Hemmann, U.; Heinrich, P.C.; Holsboer, F.; Reul, J.M. Soluble interleukin-6 (IL-6) receptor augments central effects of IL-6 in vivo. FASEB J. 1995, 9, 659-664. [CrossRef]

18. Garbers, C.; Aparicio-Siegmund, S.; Rose-John, S. The IL-6/gp130/STAT3 signaling axis: Recent advances towards specific inhibition. Curr. Opin. Immunol. 2015, 34, 75-82. [CrossRef] 
19. Lacroix, M.; Rousseau, F.; Guilhot, F.; Malinge, P.; Magistrelli, G.; Herren, S.; Jones, S.A.; Jones, G.W.; Scheller, J.; Lissilaa, R.; et al. Novel Insights into Interleukin 6 (IL-6) Cis- and Trans-signaling Pathways by Differentially Manipulating the Assembly of the IL-6 Signaling Complex. J. Biol. Chem. 2015, 290, 26943-26953. [CrossRef]

20. Garbers, C.; Jänner, N.; Chalaris, A.; Moss, M.L.; Floss, D.M.; Meyer, D.; Koch-Nolte, F.; Rose-John, S.; Scheller, J. Species specificity of ADAM10 and ADAM17 proteins in interleukin-6 (IL-6) trans-signaling and novel role of ADAM10 in inducible IL-6 receptor shedding. J. Biol. Chem. 2011, 286, 14804-14811. [CrossRef]

21. Schumacher, N.; Meyer, D.; Mauermann, A.; Von Der Heyde, J.; Wolf, J.; Schwarz, J.; Knittler, K.; Murphy, G.; Michalek, M.; Garbers, C.; et al. Shedding of Endogenous Interleukin-6 Receptor (IL-6R) Is Governed by A Disintegrin and Metalloproteinase (ADAM) Proteases while a Full-length IL-6R Isoform Localizes to Circulating Microvesicles. J. Biol. Chem. 2015, 290, 26059-26071. [CrossRef]

22. Peters, M.; Jacobs, S.; Ehlers, M.; Vollmer, P.; Müllberg, J.; Wolf, E.; Brem, G.; Büschenfelde, K.H.M.Z.; Rose-John, S. The function of the soluble interleukin 6 (IL-6) receptor in vivo: Sensitization of human soluble IL-6 receptor transgenic mice towards IL-6 and prolongation of the plasma half-life of IL-6. J. Exp. Med. 1996, 183, 1399-1406. [CrossRef]

23. Marin, V.; Montero-Julian, F.A.; Grès, S.; Boulay, V.; Bongrand, P.; Farnarier, C.; Kaplanski, G. The IL-6-Soluble IL-6R $\alpha$ Autocrine Loop of Endothelial Activation as an Intermediate Between Acute and Chronic Inflammation: An Experimental Model Involving Thrombin. J. Immunol. 2001, 167, 3435-3442. [CrossRef]

24. Croker, B.A.; Krebs, D.L.; Zhang, J.-G.; Wormald, S.; Willson, T.A.; Stanley, E.G.; Robb, L.; Greenhalgh, C.J.; Förster, I.; Clausen, B.E.; et al. SOCS3 negatively regulates IL-6 signaling in vivo. Nat. Immunol. 2003, 4, 540-545. [CrossRef]

25. Babon, J.J.; Varghese, L.N.; Nicola, N.A. Inhibition of IL-6 family cytokines by SOCS3. Semin. Immunol. 2014, 26, 13-19. [CrossRef]

26. Schmitz, J.; Weissenbach, M.; Haan, S.; Heinrich, P.C.; Schaper, F. SOCS3 Exerts Its Inhibitory Function on Interleukin-6 Signal Transduction through the SHP2 Recruitment Site of gp130. J. Biol. Chem. 2000, 275, 12848-12856. [CrossRef]

27. Zhang, L.; Badgwell, D.B.; Bevers, J.J., III; Schlessinger, K.; Murray, P.J.; Levy, D.E.; Watowich, S.S. IL-6 signaling via the STAT3/SOCS3 pathway: Functional Analysis of the Conserved STAT3 N-domain. Mol. Cell. Biochem. 2006, 288, 179-189. [CrossRef]

28. Narazaki, M.; Yasukawa, K.; Saito, T.; Ohsugi, Y.; Fukui, H.; Koishihara, Y.; Yancopoulos, G.D.; Taga, T.; Kishimoto, T. Soluble forms of the interleukin- 6 signal-transducing receptor component gp130 in human serum possessing a potential to inhibit signals through membrane-anchored gp130. Blood 1993, 82, 1120-1126. [CrossRef]

29. Yasukawa, K.; Futatsugi, K.; Saito, T.; Yawata, H.; Narazaki, M.; Suzuki, H.; Taga, T.; Kishimoto, T. Association of recombinant soluble IL-6-signal transducer, gp130, with a complex of IL 6 and soluble IL-6 receptor, and establishment of an ELISA for soluble gp130. Immunol. Lett. 1992, 31, 123-130. [CrossRef]

30. Wolf, J.; Waetzig, G.H.; Chalaris, A.; Reinheimer, T.M.; Wege, H.; Rose-John, S.; Garbers, C. Different Soluble Forms of the Interleukin-6 Family Signal Transducer gp130 Fine-tune the Blockade of Interleukin-6 Trans-signaling. J. Biol. Chem. 2016, 291, 16186-16196. [CrossRef]

31. Heinrich, P.C.; Behrmann, I.; Haan, S.; Hermanns, H.M.; Müller-Newen, G.; Schaper, F. Principles of interleukin (IL)-6-type cytokine signalling and its regulation. Biochem. J. 2003, 374, 1-20. [CrossRef]

32. Tanaka, T.; Narazaki, M.; Kishimoto, T. IL-6 in inflammation, immunity, and disease. Cold Spring Harb. Perspect. Biol. 2014, 6, a016295. [CrossRef]

33. Heinrich, P.C.; Castell, J.V.; Andus, T. Interleukin-6 and the acute phase response. Biochem. J. 1990, 265, 621-636. [CrossRef]

34. Nemeth, E.; Rivera, S.; Gabayan, V.; Keller, C.; Taudorf, S.; Pedersen, B.K.; Ganz, T. IL-6 mediates hypoferremia of in-flammation by inducing the synthesis of the iron regulatory hormone hepcidin. J. Clin. Investig. 2004, 113, 1271-1276. [CrossRef]

35. Liuzzi, J.P.; Lichten, L.A.; Rivera, S.; Blanchard, R.K.; Aydemir, T.B.; Knutson, M.D.; Ganz, T.; Cousins, R.J. Interleukin-6 regulates the zinc transporter Zip14 in liver and contributes to the hypozincemia of the acute-phase response. Proc. Natl. Acad. Sci. USA 2005, 102, 6843-6848. [CrossRef]

36. Korn, T.; Bettelli, E.; Oukka, M.; Kuchroo, V.K. IL-17 and Th17 Cells. Annu. Rev. Immunol. 2009, 27, 485-517. [CrossRef]

37. Bettelli, E.; Carrier, Y.; Gao, W.; Korn, T.; Strom, T.B.; Oukka, M.; Weiner, H.L.; Kuchroo, V.K. Reciprocal developmental pathways for the generation of pathogenic effector TH17 and regulatory T cells. Nature 2006, 441, 235-238. [CrossRef]

38. Kimura, A.; Kishimoto, T. IL-6: Regulator of Treg/Th17 balance. Eur. J. Immunol. 2010, 40, 1830-1835. [CrossRef]

39. Ma, C.S.; Deenick, E.K.; Batten, M.; Tangye, S.G. The origins, function, and regulation of T follicular helper cells. J. Exp. Med. 2012, 209, 1241-1253. [CrossRef]

40. Okada, M.; Kitahara, M.; Kishimoto, S.; Matsuda, T.; Hirano, T.; Kishimoto, T. IL-6/BSF-2 functions as a killer helper factor in the in vitro induction of cytotoxic T cells. J. Immunol. 1988, 141, 1543-1549.

41. Kaneko, Y.; Takeuchi, T. An update on the pathogenic role of IL-6 in rheumatic diseases. Cytokine 2021, 146, 155645. [CrossRef] [PubMed]

42. Bondeson, J.; Wainwright, S.D.; Lauder, S.; Amos, N.; Hughes, C.E. The role of synovial macrophages and macrophage-produced cytokines in driving aggrecanases, matrix metalloproteinases, and other destructive and inflammatory responses in osteoarthritis. Arthritis Res. Ther. 2006, 8, R187. [CrossRef] [PubMed]

43. Yoshitake, F.; Itoh, S.; Narita, H.; Ishihara, K.; Ebisu, S. Interleukin-6 Directly Inhibits Osteoclast Differentiation by Suppressing Receptor Activator of NF-kB Signaling Pathways. J. Biol. Chem. 2008, 283, 11535-11540. [CrossRef] [PubMed] 
44. Muangchan, C.; Pope, J.E. Interleukin 6 in Systemic Sclerosis and Potential Implications for Targeted Therapy. J. Rheumatol. 2012, 39, 1120-1124. [CrossRef] [PubMed]

45. Fuschiotti, P.; Medsger, T.A., Jr.; Morel, P.A. Effector CD8 ${ }^{+}$T cells in systemic sclerosis patients produce abnormally high levels of interleukin-13 associated with increased skin fibrosis. Arthritis Care Res. 2009, 60, 1119-1128. [CrossRef]

46. Yoshizaki, K. Pathogenic Role of IL-6 Combined with TNF- $\alpha$ or IL-1 in the Induction of Acute Phase Proteins SAA and CRP in Chronic Inflammatory Diseases. Adv. Exp. Med. Biol. 2010, 691, 141-150. [CrossRef]

47. Saito, F.; Tasaka, S.; Inoue, K.-I.; Miyamoto, K.; Nakano, Y.; Ogawa, Y.; Yamada, W.; Shiraishi, Y.; Hasegawa, N.; Fujishima, S.; et al Role of Interleukin-6 in Bleomycin-Induced Lung Inflammatory Changes in Mice. Am. J. Respir. Cell Mol. Biol. $2008,38,566-571$. [CrossRef]

48. Fishman, D.; Faulds, G.; Jeffery, R.; Mohamed-Ali, V.; Yudkin, J.S.; Humphries, S.; Woo, P. The effect of novel polymorphisms in the interleukin-6 (IL-6) gene on IL-6 transcription and plasma IL-6 levels, and an association with systemic-onset juvenile chronic arthritis. J. Clin. Investig. 1998, 102, 1369-1376. [CrossRef]

49. Steen, V.D.; Medsger, T.A., Jr. Severe organ involvement in systemic sclerosis with diffuse scleroderma. Arthritis Rheum. 2000, 43 2437-2444. [CrossRef]

50. Khanna, D.; Hays, R.D.; Maranian, P.; Seibold, J.R.; Impens, A.; Mayes, M.D.; Clements, P.J.; Getzug, T.; Fathi, N.; Bechtel, A.; et al Reliability and validity of the university of california, los angeles scleroderma clinical trial consortium gastrointestinal tract instrument. Arthritis Care Res. 2009, 61, 1257-1263. [CrossRef]

51. Sfrent-Cornateanu, R.; Mihai, C.; Balan, S.; Ionescu, R.; Moldoveanu, E. The IL -6 promoter polymorphism is associated with disease activity and disability in systemic sclerosis. J. Cell. Mol. Med. 2006, 10, 890-895. [CrossRef]

52. Needleman, B.W.; Wigley, F.M.; Stair, R.W. Interleukin-1, Interleukin-2, Interleukin-4, Interleukin-6, Tumor Necrosis Factor $\alpha$, and Interferon- $\gamma$ Levels in Sera from Patients with Scleroderma. Arthritis Care Res. 1992, 35, 67-72. [CrossRef]

53. Koch, A.E.; Kronfeld-Harrington, L.B.; Szekanecz, Z.; Cho, M.M.; Haines, K.; Harlow, L.A.; Strieter, R.M.; Kunkel, S.L.; Massa, M.C.; Barr, W.G.; et al. In situ Expression of Cytokines and Cellular Adhesion Molecules in the Skin of Patients with Systemic Sclerosis. Their role in early and late disease. Pathobiology 1993, 61, 239-246. [CrossRef]

54. Barnes, T.C.; Spiller, D.G.; Anderson, M.E.; Edwards, S.W.; Moots, R.J. Endothelial activation and apoptosis mediated by neutrophil-dependent interleukin 6 trans-signalling: A novel target for systemic sclerosis? Ann. Rheum. Dis. 2011, 70, 366-372 [CrossRef]

55. Henderson, J.; Bhattacharyya, S.; Varga, J.; O'Reilly, S. Targeting TLRs and the inflammasome in systemic sclerosis. Pharmacol. Ther. 2018, 192, 163-169. [CrossRef]

56. Feghali, C.A.; Bost, K.L.; Boulware, D.W.; Levy, L.S. Mechanisms of pathogenesis in scleroderma. I. Overproduction of in-terleukin 6 by fibroblasts cultured from affected skin sites of patients with scleroderma. J. Rheumatol. 1992, 19, 1207-1211.

57. Gurram, M.; Pahwa, S.; Frieri, M. Augmented interleukin-6 secretion in collagen-stimulated peripheral blood mononuclear cells from patients with systemic sclerosis. Ann. Allergy 1994, 73, 493-496.

58. Hasegawa, M.; Fujimoto, M.; Matsushita, T.; Hamaguchi, Y.; Takehara, K.; Sato, S. Serum chemokine and cytokine levels as indicators of disease activity in patients with systemic sclerosis. Clin. Rheumatol. 2011, 30, 231-237. [CrossRef]

59. Giacomelli, R.; Cipriani, P.; Danese, C.; Pizzuto, F.; Lattanzio, R.; Parzanese, I.; Passacantando, A.; Perego, M.A.; Tonietti, G. Peripheral blood mononuclear cells of patients with systemic sclerosis produce increased amounts of interleukin 6 , but not transforming growth factor beta 1. J. Rheumatol. 1996, 23, 291-296.

60. Sato, S.; Hasegawa, M.; Takehara, K. Serum levels of interleukin-6 and interleukin-10 correlate with total skin thickness score in patients with systemic sclerosis. J. Dermatol. Sci. 2001, 27, 140-146. [CrossRef]

61. Hasegawa, M.; Sato, S.; Fujimoto, M.; Ihn, H.; Kikuchi, K.; Takehara, K. Serum levels of interleukin 6 (IL-6), oncostatin M, soluble IL-6 receptor, and soluble gp130 in patients with systemic sclerosis. J. Rheumatol. 1998, 25, 308-313. [PubMed]

62. Matsushita, T.; Hasegawa, M.; Hamaguchi, Y.; Takehara, K.; Sato, S. Longitudinal analysis of serum cytokine concentrations in systemic sclerosis: Association of interleukin 12 elevation with spontaneous regression of skin sclerosis. J. Rheumatol. 2006, 33, 275-284. [PubMed]

63. Shima, Y.; Kawaguchi, Y.; Kuwana, M. Add-on tocilizumab versus conventional treatment for systemic sclerosis, and cytokine analysis to identify an endotype to tocilizumab therapy. Mod. Rheumatol. 2019, 29, 134-139. [CrossRef] [PubMed]

64. Yamauchi-Takihara, K.; Kishimoto, T. Cytokines and their receptors in cardiovascular diseases-Role of gp130 signalling pathway in cardiac myocyte growth and maintenance. Int. J. Exp. Pathol. 2000, 81, 1-16. [CrossRef]

65. Rajkumar, V.S.; Howell, K.; Csiszar, K.; Denton, C.P.; Black, C.M.; Abraham, D.J. Shared expression of phenotypic markers in systemic sclerosis indicates a convergence of pericytes and fibroblasts to a myofibroblast lineage in fibrosis. Arthritis Res. Ther. 2005, 7, R1113-R1123. [CrossRef]

66. Kitaba, S.; Murota, H.; Terao, M.; Azukizawa, H.; Terabe, F.; Shima, Y.; Fujimoto, M.; Tanaka, T.; Naka, T.; Kishimoto, T.; et al. Blockade of Interleukin-6 Receptor Alleviates Disease in Mouse Model of Scleroderma. Am. J. Pathol. 2012, 180, 165-176. [CrossRef] [PubMed]

67. Kawaguchi, Y.; Hara, M.; Wright, T.M. Endogenous IL-1 $\alpha$ from systemic sclerosis fibroblasts induces IL-6 and PDGF-A. J. Clin. Investig. 1999, 103, 1253-1260. [CrossRef]

68. Beon, M.; Harley, R.A.; Wessels, A.; Silver, R.M.; Ludwicka-Bradley, A. Myofibroblast induction and microvascular alteration in scleroderma lung fibrosis. Clin. Exp. Rheumatol. 2004, 22, 733-742. 
69. Brissett, M.; Veraldi, K.L.; Pilewski, J.M.; Medsger, T.A., Jr.; Feghali-Bostwick, C.A. Localized expression of tenascin in systemic sclerosis-associated pulmonary fibrosis and its regulation by insulin-like growth factor binding protein 3. Arthritis Care Res. 2012, 64, 272-280. [CrossRef]

70. Crestani, B.; Seta, N.; De Bandt, M.; Soler, P.; Rolland, C.; Dehoux, M.; Boutten, A.; Dombret, M.C.; Palazzo, E.; Kahn, M.F. Interleukin 6 secretion by monocytes and alveolar macrophages in systemic sclerosis with lung involvement. Am. J. Respir. Crit. Care Med. 1994, 149, 1260-1265. [CrossRef] [PubMed]

71. Renaud, L.; da Silveira, W.A.; Takamura, N.; Hardiman, G.; Feghali-Bostwick, C. Prominence of IL6, IGF, TLR, and Bioenergetics Pathway Perturbation in Lung Tissues of Scleroderma Patients with Pulmonary Fibrosis. Front. Immunol. 2020, 11, 383. [CrossRef]

72. Le, T.-T.T.; Karmouty-Quintana, H.; Melicoff, E.; Le, T.-T.T.; Weng, T.; Chen, N.-Y.; Pedroza, M.; Zhou, Y.; Davies, J.; Philip, K.; et al. Blockade of IL-6 Trans Signaling Attenuates Pulmonary Fibrosis. J. Immunol. 2014, 193, 3755-3768. [CrossRef]

73. De Lauretis, A.; Sestini, P.; Pantelidis, P.; Hoyles, R.; Hansell, D.M.; Goh, N.S.; Zappala, C.J.; Visca, D.; Maher, T.M.; Denton, C.P.; et al. Serum Interleukin 6 Is Predictive of Early Functional Decline and Mortality in Interstitial Lung Disease Associated with Systemic Sclerosis. J. Rheumatol. 2013, 40, 435-446. [CrossRef]

74. Khan, K.; Xu, S.; Nihtyanova, S.; Derrett-Smith, E.; Abraham, D.; Denton, C.P.; Ong, V.H. Clinical and pathological significance of interleukin 6 overexpression in systemic sclerosis. Ann. Rheum. Dis. 2012, 71, 1235-1242. [CrossRef]

75. Giuggioli, D.; Lumetti, F.; Colaci, M.; Fallahi, P.; Antonelli, A.; Ferri, C. Rituximab in the treatment of patients with systemic sclerosis. Our experience and review of the literature. Autoimmun. Rev. 2015, 14, 1072-1078. [CrossRef]

76. Bosello, S.; De Santis, M.; Lama, G.; Spanò, C.; Angelucci, C.; Tolusso, B.; Sica, G.; Ferraccioli, G. B cell depletion in diffuse progressive systemic sclerosis: Safety, skin score modification and IL-6 modulation in an up to thirty-six months follow-up open-label trial. Arthritis Res. Ther. 2010, 12, R54. [CrossRef]

77. Abignano, G.; Del Galdo, F. Biomarkers as an opportunity to stratify for outcome in systemic sclerosis. Eur. J. Rheumatol. 2020, 7, 193-202. [CrossRef]

78. Abdel-Magied, R.A.; Kamel, S.; Said, A.F.; Ali, H.M.; Gawad, E.A.A.; Moussa, M.M. WITHDRAWN: Serum interleukin-6 in systemic sclerosis and its correlation with disease parameters and cardiopulmonary involvement. Egypt. J. Chest Dis. Tuberc. 2016, 33, 32. [CrossRef]

79. Pendergrass, S.A.; Hayes, E.; Farina, G.; Lemaire, R.; Farber, H.W.; Whitfield, M.L.; Lafyatis, R. Limited Systemic Sclerosis Patients with Pulmonary Arterial Hypertension Show Biomarkers of Inflammation and Vascular Injury. PLoS ONE 2010, 5 , e12106. [CrossRef]

80. Steen, V.; Medsger, T.A., Jr. Predictors of isolated pulmonary hypertension in patients with systemic sclerosis and limited cutaneous involvement. Arthritis Care Res. 2003, 48, 516-522. [CrossRef]

81. Dorfmüller, P.; Humbert, M.; Perros, F.; Sanchez, O.; Simonneau, G.; Müller, K.-M.; Capron, F. Fibrous remodeling of the pulmonary venous system in pulmonary arterial hypertension associated with connective tissue diseases. Hum. Pathol. 2007, 38, 893-902. [CrossRef]

82. Kawut, S.M.; Taichman, D.B.; Archer-Chicko, C.L.; Palevsky, H.I.; Kimmel, S.E. Hemodynamics and Survival in Patients with Pulmonary Arterial Hypertension Related to Systemic Sclerosis. Chest 2003, 123, 344-350. [CrossRef]

83. Fisher, M.R.; Mathai, S.C.; Champion, H.C.; Girgis, R.E.; Housten-Harris, T.; Hummers, L.; Krishnan, J.A.; Wigley, F.; Hassoun, P.M. Clinical differences between idiopathic and scleroderma-related pulmonary hypertension. Arthritis Care Res. 2006, 54, 3043-3050. [CrossRef]

84. Cool, C.D.; Kennedy, D.; Voelkel, N.F.; Tuder, R.M. Pathogenesis and evolution of plexiform lesions in pulmonary hypertension associated with scleroderma and human immunodeficiency virus infection. Hum. Pathol. 1997, 28, 434-442. [CrossRef]

85. Sjogren, R.W. Gastrointestinal motility disorders in scleroderma. Arthritis Care Res. 1994, 37, 1265-1282. [CrossRef]

86. Cénit, M.C.; Simeón, C.P.; Vonk, M.C.; Callejas-Rubio, J.L.; Espinosa, G.; Carreira, P.; Blanco, F.J.; Narvaez, J.; Tolosa, C.; Román-Ivorra, J.A.; et al. Influence of the IL6 Gene in Susceptibility to Systemic Sclerosis. J. Rheumatol. 2012, 39, $2294-2302$. [CrossRef]

87. Zekovic, A.; Vreća, M.; Spasovski, V.; Andjelković, M.; Pavlovic, S.; Damjanov, N. Association between the -174 C/G polymorphism in the interleukin-6 (IL-6) gene and gastrointestinal involvement in patients with systemic sclerosis. Clin. Rheumatol. 2018 37, 2447-2454. [CrossRef]

88. Campbell, P.M.; LeRoy, E.C. Pathogenesis of systemic sclerosis: A vascular hypothesis. Semin. Arthritis Rheum. 1975, 4, 351-368. [CrossRef]

89. Steen, V.D.; Medsger, T.A., Jr. The value of the health assessment questionnaire and special patient-generated scales to demonstrate change in systemic sclerosis patients over time. Arthritis Care Res. 1997, 40, 1984-1991. [CrossRef]

90. Taroni, J.N.; Martyanov, V.; Huang, C.-C.; Mahoney, J.M.; Hirano, I.; Shetuni, B.; Yang, G.-Y.; Brenner, D.; Jung, B.; Wood, T.A.; et al. Molecular characterization of systemic sclerosis esophageal pathology identifies inflammatory and proliferative signatures. Arthritis Res. Ther. 2015, 17, 194. [CrossRef]

91. Thoua, N.M.; Abdel-Halim, M.; Forbes, A.; Denton, C.P.; Emmanuel, A.V. Fecal Incontinence in Systemic Sclerosis Is Secondary to Neuropathy. Am. J. Gastroenterol. 2012, 107, 597-603. [CrossRef]

92. Singh, J.; Mehendiratta, V.; Del Galdo, F.; Jimenez, S.; Cohen, S.; Dimarino, A.J.; Rattan, S. Immunoglobulins from scleroderma patients inhibit the muscarinic receptor activation in internal anal sphincter smooth muscle cells. Am. J. Physiol. Liver Physiol. 2009, 297, G1206-G1213. [CrossRef] 
93. Hong, B.Y.; Giang, R.; Mbuagbaw, L.; Larche, M.; Thabane, L. Factors associated with development of gastrointestinal problems in patients with scleroderma: A systematic review. Syst. Rev. 2015, 4, 188. [CrossRef]

94. Fertig, N.; Domsic, R.T.; Rodriguez-Reyna, T.; Kuwana, M.; Lucas, M.; Medsger, T.A., Jr.; Feghali-Bostwick, C.A. Anti-U11/U12 RNP antibodies in systemic sclerosis: A new serologic marker associated with pulmonary fibrosis. Arthritis Care Res. 2009, 61, 958-965. [CrossRef]

95. Kawaguchi, Y.; Nakamura, Y.; Matsumoto, I.; Nishimagi, E.; Satoh, T.; Kuwana, M.; Sumida, T.; Hara, M. Muscarinic-3 acetylcholine receptor autoantibody in patients with systemic sclerosis: Contribution to severe gastrointestinal tract dysmotility. Ann. Rheum. Dis. 2009, 68, 710-714. [CrossRef]

96. Marie, I.; Leroi, A.-M.; Menard, J.-F.; Levesque, H.; Quillard, M.; Ducrotte, P. Fecal calprotectin in systemic sclerosis and review of the literature. Autoimmun. Rev. 2015, 14, 547-554. [CrossRef]

97. Miller, J.B.; Gandhi, N.; Clarke, J.; Mcmahan, Z. Gastrointestinal Involvement in Systemic Sclerosis. JCR J. Clin. Rheumatol. 2018, 24, 328-337. [CrossRef]

98. Denton, C.P.; Black, C.M. Scleroderma-Clinical and pathological advances. Best Pr. Res. Clin. Rheumatol. 2004, 18, 271-290. [CrossRef]

99. Penn, H.; Howie, A.J.; Kingdon, E.J.; Bunn, C.; Stratton, R.; Black, C.; Burns, A.; Denton, C. Scleroderma renal crisis: Patient characteristics and long-term outcomes. QJM Int. J. Med. 2007, 100, 485-494. [CrossRef]

100. Stern, E.P.; Guerra, S.G.; Chinque, H.; Acquaah, V.; González-Serna, D.; Ponticos, M.; Martin, J.; Ong, V.H.; Khan, K.; Nihtyanova, S.I.; et al. Analysis of Anti-RNA Polymerase III Antibody-positive Systemic Sclerosis and Altered GPATCH2L and CTNND2 Expression in Scleroderma Renal Crisis. J. Rheumatol. 2020, 47, 1668-1677. [CrossRef]

101. Liu, C.; Hou, Y.; Xu, D.; Li, L.; Zhang, Y.; Cheng, L.; Yan, S.; Zhang, F.; Li, Y. Analysis of anti-RNA polymerase III antibodies in Chinese Han systemic sclerosis patients. Clin. Rheumatol. 2020, 39, 1191-1197. [CrossRef]

102. Scala, E.; Pallotta, S.; Frezzolini, A.; Abeni, D.; Barbieri, C.; Sampogna, F.; DE Pità, O.; Puddu, P.; Paganelli, R.; Russo, G. Cytokine and chemokine levels in systemic sclerosis: Relationship with cutaneous and internal organ involvement. Clin. Exp. Immunol. 2004, 138, 540-546. [CrossRef]

103. Doran, J.P.; Veale, D.J. Biomarkers in systemic sclerosis. Rheumatology 2008, 47, v36-v38. [CrossRef]

104. Lee, S.; Lee, S.; Sharma, K. The pathogenesis of fibrosis and renal disease in scleroderma: Recent insights from glomerulosclerosis. Curr. Rheumatol. Rep. 2004, 6, 141-148. [CrossRef]

105. Charles, C.; Clements, P.; Furst, D.F. Systemic sclerosis: Hypothesis-driven treatment strategies. Lancet 2006, 367, 1683-1691. [CrossRef]

106. Steen, V.D. Scleroderma renal crisis. Rheum. Dis. Clin. North Am. 2003, 29, 315-333. [CrossRef]

107. Steen, V.D.; Medsger, T.A., Jr. Long-Term Outcomes of Scleroderma Renal Crisis. Ann. Intern. Med. 2000, 133, 600-603. [CrossRef]

108. Mihara, M.; Kasutani, K.; Okazaki, M.; Nakamura, A.; Kawai, S.; Sugimoto, M.; Matsumoto, Y.; Ohsugi, Y. Tocilizumab inhibits signal transduction mediated by both mIL-6R and sIL-6R, but not by the receptors of other members of IL-6 cytokine family. Int Immunopharmacol. 2005, 5, 1731-1740. [CrossRef]

109. Burmester, G.R.; Feist, E.; Kellner, H.; Braun, J.; Iking-Konert, C.; Rubbert-Roth, A. Effectiveness and safety of the interleukin 6-receptor antagonist tocilizumab after 4 and 24 weeks in patients with active rheumatoid arthritis: The first phase IIIb real-life study (TAMARA). Ann. Rheum. Dis. 2011, 70, 755-759. [CrossRef]

110. Ohsugi, Y. The immunobiology of humanized Anti-IL6 receptor antibody: From basic research to breakthrough medicine. J. Transl. Autoimmun. 2020, 3, 100030. [CrossRef]

111. Castañeda, S.; Martínez-Quintanilla, D.; Martín-Varillas, J.L.; García-Castañeda, N.; Atienza-Mateo, B.; González-Gay, M.A Tocilizumab for the treatment of adult-onset Still's disease. Expert Opin. Biol. Ther. 2019, 19, 273-286. [CrossRef]

112. Stone, J.H.; Tuckwell, K.; Dimonaco, S.; Klearman, M.; Aringer, M.; Blockmans, D.E.; Brouwer, E.; Cid, M.C.; Dasgupta, B.; Rech, J.; et al. Trial of Tocilizumab in Giant-Cell Arteritis. N. Engl. J. Med. 2017, 377, 317-328. [CrossRef]

113. Abid, M.B.; Peck, R.; Abid, M.A.; Al-Sakkaf, W.; Zhang, Y.; Dunnill, G.S.; Staines, K.; Sequeiros, I.-M.; Lowry, L. Is tocilizumab a potential therapeutic option for refractory unicentric Castleman disease? Hematol. Oncol. 2017, 36, 320-323. [CrossRef]

114. Khanna, D.; Denton, C.P.; Jahreis, A.; van Laar, J.M.; Frech, T.M.; Anderson, M.E.; Baron, M.; Chung, L.; Fierlbeck, G.; Lakshminarayanan, S.; et al. Safety and efficacy of subcutaneous tocilizumab in adults with systemic sclerosis (faSScinate): A phase 2, randomised, controlled trial. Lancet 2016, 387, 2630-2640. [CrossRef]

115. Khanna, D.; Lin, C.J.F.; Kuwana, M.; Allanore, Y.; Batalov, A.; Butrimiene, I.; Carreira, P.; Matucci Cerinic, M.; Distler, O.; Kaliterna, D.M.; et al. Efficacy and Safety of Tocilizumab for the Treatment of Systemic Sclerosis: Results from a Phase 3 Randomized Controlled Trial [abstract]. Arthritis Rheumatol. 2018, 70, 1000-1002.

116. Denton, C.P.; Ong, V.H.; Xu, S.; Chen-Harris, H.; Modrusan, Z.; Lafyatis, R.; Khanna, D.; Jahreis, A.; Siegel, J.; Sornasse, T. Therapeutic interleukin-6 blockade reverses transforming growth factor-beta pathway activation in dermal fibroblasts: Insights from the faSScinate clinical trial in systemic sclerosis. Ann. Rheum. Dis. 2018, 77, 1362-1371. [CrossRef]

117. Shima, Y.; Kuwahara, Y.; Murota, H.; Kitaba, S.; Kawai, M.; Hirano, T.; Arimitsu, J.; Narazaki, M.; Hagihara, K.; Ogata, A.; et al. The skin of patients with systemic sclerosis softened during the treatment with anti-IL-6 receptor antibody tocilizumab. Rheumatology 2010, 49, 2408-2412. [CrossRef]

118. Zacay, G.; Levy, Y. Outcomes of patients with systemic sclerosis treated with tocilizumab: Case series and review of the literature. Best Pr. Res. Clin. Rheumatol. 2018, 32, 563-571. [CrossRef] 
119. Elhai, M.; Meunier, M.; Matucci-Cerinic, M.; Maurer, B.; Riemekasten, G.; Leturcq, T.; Pellerito, R.; Von Mühlen, C.A.; Vacca, A.; Airo, P.; et al. Outcomes of patients with systemic sclerosis-associated polyarthritis and myopathy treated with tocilizumab or abatacept: A EUSTAR observational study. Ann. Rheum. Dis. 2013, 72, 1217-1220. [CrossRef]

120. Fernández-Codina, A.; Walker, K.M.; Pope, J.E. Treatment Algorithms for Systemic Sclerosis According to Experts. Arthritis Rheumatol. 2018, 70, 1820-1828. [CrossRef]

121. Khanna, D.; Lin, C.J.F.; Furst, D.E.; Goldin, J.; Kim, G.; Kuwana, M.; Allanore, Y.; Matucci-Cerinic, M.; Distler, O.; Shima, Y.; et al. Tocilizumab in systemic sclerosis: A randomised, double-blind, placebo-controlled, phase 3 trial. Lancet Respir. Med. 2020, 8 , 963-974. [CrossRef]

122. Khanna, D.; Jahreis, A.; Furst, D.E. Tocilizumab Treatment of Patients with Systemic Sclerosis: Clinical Data. J. Scleroderma Relat. Disord. 2017, 2, S29-S35. [CrossRef]

123. Roofeh, D.; Lin, C.J.F.; Goldin, J.; Kim, G.H.; Furst, D.E.; Denton, C.P.; Huang, S.; Khanna, D. Tocilizumab Prevents Progression of Early Systemic Sclerosis-Associated Interstitial Lung Disease. Arthritis Rheumatol. 2021, 73, 1301-1310. [CrossRef]

124. Narváez, J.; Lluch, J.; Alegre Sancho, J.J.A.; Molina-Molina, M.; Nolla, J.M.; Castellvi, I. Effectiveness and safety of tocilizumab for the treatment of refractory systemic sclerosis associated interstitial lung disease: A case series. Ann. Rheum. Dis. 2019, 78, e123. [CrossRef]

125. Khanna, D.; Lin, C.J.F.; Furst, D.E.; Wagner, B.; Zucchetto, M.; Raghu, G.; Martinez, F.J.; Goldin, J.; Siegel, J.; Denton, C.P.; et al. Long-Term Safety and Efficacy of Tocilizumab in Early Systemic Sclerosis-Interstitial Lung Disease: Open Label Extension of a Phase 3 Randomized Controlled Trial. Am. J. Respir. Crit. Care Med. 2021, 204, 1245-1252. [CrossRef]

126. Panopoulos, S.T.; Tektonidou, M.G.; Bournia, V.-K.; Arida, A.; Sfikakis, P.P. Anti-interleukin 6 Therapy Effect for Refractory Joint and Skin Involvement in Systemic Sclerosis: A Real-world, Single-center Experience. J. Rheumatol. 2022, 49, 68-73. [CrossRef]

127. Kahan, A.; Allanore, Y. Primary myocardial involvement in systemic sclerosis. Rheumatology 2006, 45, iv14-iv17. [CrossRef]

128. Meléndez, G.C.; McLarty, J.L.; Levick, S.P.; Du, Y.; Janicki, J.S.; Brower, G.L. Interleukin 6 Mediates Myocardial Fibrosis, Concentric Hypertrophy, and Diastolic Dysfunction in Rats. Hypertension 2010, 56, 225-231. [CrossRef]

129. Ishizaki, Y.; Ooka, S.; Doi, S.; Kawasaki, T.; Sakurai, K.; Mizushima, M.; Kiyokawa, T.; Takakuwa, Y.; Tonooka, K.; Kawahata, K. Treatment of myocardial fibrosis in systemic sclerosis with tocilizumab. Rheumatology 2020, 60, e205-e206. [CrossRef]

130. Adrovic, A.; Yildiz, M.; Haslak, F.; Koker, O.; Aliyeva, A.; Sahin, S.; Barut, K.; Kasapcopur, O. Tocilizumab therapy in juvenile systemic sclerosis: A retrospective single centre pilot study. Rheumatol. Int. 2021, 41, 121-128. [CrossRef] 